\title{
IMAGENS ARQUETÍPICAS NA OBRA DE ERNESTO SABATO: UM ESTUDO COMPARADO ENTRE SUA PINTURA E O ROMANCE O TÚNEL
}

\author{
ARCHETYPAL IMAGES IN THE WORK OF ERNESTO SABATO: A COMPARED \\ STUDY BETWEEN HIS PAINTING AND THE NOVEL THE TUNNEL
}

\author{
Recebido: 22/10/2020 Aprovado: 01/12/2020 Publicado: 10/01/2021
}

DOI: $10.18817 /$ rlj.v4i02.2398

\begin{abstract}
Vilma Rodrigues Mascarenhas ${ }^{1}$ Orcid id: https://orcid.org/0000-0003-3924-8567

José Wanderson Lima Torres ${ }^{2}$ Orcid id: https://orcid.org/0000-0003-2304-0681
\end{abstract}

\begin{abstract}
RESUMO: O presente artigo apresenta uma análise intertextual das imagens arquetípicas do romance O Túnel (1948), do escritor argentino Ernesto Sabato, e a relação intersemiótica com as pinturas do escritor, oportunizando, dessa forma, uma análise comparativa ainda não explorada da obra. Este estudo fundamenta-se na perspectiva da Psicologia Analítica aplicada à metodologia da Literatura Comparada como instrumento da Crítica Literária, com base na imagem arquetípica da sombra como fio condutor da narrativa sabatiana, pois se trata da confissão de um crime passional narrada por Juan Pablo Castel, protagonista do romance. O apoio teórico provém dos estudos de Bolen (2002), Jung (2002, 2013, 2015), Meletínski (2002) e Sabato (2000a, 2000b, 2003), estabelecendo-se um diálogo com as pinturas de Sabato intituladas Algo ocorrido em meu Ateliê (1994) e Alguém observa o ateliê de um pintor ausente (1981), que ressignificam as sombras arquetípicas do texto literário para o texto pictórico, expressas no uso excessivo de tonalidades escuras, no sentido expressionista e perturbador dos personagens e no simbolismo da morte nas pinturas do autor. Portanto, o processo intersemiótico do texto literário de O Túnel (1948) para o universo pictórico configura-se como extensão da narrativa, revelando a simbologia arquetípica das imagens como instrumento crítico na interpretação das linguagens literária e visual.
\end{abstract}

Palavras-chave: O Túnel. Imagens Arquetípicas. Literatura. Psicologia Analítica.

ABSTRACT: This article presents an intertextual analysis of the archetypal images of the novel The Tunnel (1948), by the Argentine writer Ernesto Sabato and the intersemiotic relationship with the writer's paintings, thus providing an opportunity for a comparative analysis not yet explored of the work. This study is based on the perspective of Analytical Psychology applied to the methodology of Comparative Literature as an instrument of Literary Criticism, based on the archetypal image of the shadow as the guiding thread of the Sabato's narrative, it is the confession of a passionate crime narrated by Juan Pablo Castel, protagonist of the novel. The theoretical support comes from the studies of Bolen (2002), Jung (2002, 2013, 2015), Meletínski (2002) and Sabato (2000a, 2000b, 2003), in the dialogue with Sabato's paintings: Something that happened in my studio (1994) ) and Someone observes the studio of an absent painter (1981) that resignify the archetypal shadows of the literary text to the pictorial text, expressed in the excessive use of dark tones, in the expressionist and disturbing sense of the characters and in the symbolism of death in the author's paintings. Thus, the intersemiotic process of the literary text of The Tunnel (1948) for the pictorial universe is configured as an extension of the narrative, revealing the archetypal symbology of images as a critical instrument in the interpretation of literary and visual languages.

\footnotetext{
${ }_{1}^{1}$ Mestre em Literatura, Memória e Cultura; Especialista em Linguística e Ensino; Graduada em Letras/ Inglês, pela Universidade Estadual do Piauí (UESPI). Graduada em Educação Artística, pela Universidade Federal do Piauí (UFPI). Membro da União dos Artistas Plásticos do Piauí (UAPPI). Email: vilma-mascarenhas@hotmail.com

2 É professor Adjunto II da Universidade Estadual do Piauí (UESPI) - Campus Clóvis Moura -Teresina. Possui Mestrado em Letras pela UFPI (2004-2005) e Doutorado em Estudos da Linguagem pela UFRN (2008-2012). Professor do Mestrado Acadêmico em Letras da UESPI. E-mail: wandersontorres@hotmail.com
} 
Keywords: The Tunnel. Archetypal Images. Literature. Analytical Psychology.

\section{A Psicologia como instrumento da crítica literária}

A Psicologia Analítica foi fundada no início do século XX pelo psiquiatra suíço Carl Gustav Jung (1875-1961), com base no amplo conhecimento das tradições culturais, da alquimia, da mitologia e do estudo comparado da história das religiões, visando à compreensão das representações coletivas nos processos psíquicos inconscientes, nos quais residem as imagens arquetípicas $^{3}$, que dialogam universalmente conosco por várias gerações. A teoria psicanalítica estuda o inconsciente humano, considerando as camadas individual e coletiva. A primeira consiste na individualidade psíquica, na qual é mantida toda a experiência pessoal, contrapondo-se às possíveis implicações psicológicas do inconsciente coletivo, a área mais profunda da mente que pertence a todos os seres humanos. Nessa segunda camada, estão armazenadas as imagens primordiais denominadas "arquétipos", que constituem objeto de estudo da teoria junguiana. Nessa perspectiva, ao analisar o simbolismo das imagens no texto literário de $O$ Túnel, recorremos à crítica junguiana como uma das ferramentas eficazes de interpretação.

Em O espírito na arte e na ciência, Jung (2013) lança o olhar da Psicologia Analítica sobre o processo da criação da obra de arte, que se manifesta psicologicamente como a canalização das mensagens oriundas do inconsciente coletivo para a humanidade. O psiquiatra ressalta que o objeto estético não é analisado como fuga, mas como uma descoberta que leva o indivíduo a ressignificálo artisticamente. Devido a importância cultural que as obras de arte trazem em si, Jung propugna que elas não sejam avaliadas cientificamente, induzindo, dessa forma, o reducionismo de sua interpretação apenas ao campo estético ou ao clínico. Nesse sentido, o estudo dos arquétipos evidencia uma riqueza polissêmica das metáforas e dos símbolos concebidos pela oposição dos fatores conscientes e inconscientes, unificados no objeto artístico, passível de uma ampla interpretação.

Leite (2002) afirma que Jung considera a análise de um texto literário como um real desafio, uma vez que leva o pesquisador a interpretar simbolicamente aquilo

\footnotetext{
${ }^{1}$ Tomamos como conceito de "imagens arquetípicas" as formas simbólicas do inconsciente coletivo, que é o conteúdo compartilhado por pessoas de todas as épocas e culturas (JUNG, 2002), assim materializado nas pinturas e no texto literário de Ernesto Sabato.
} 
que na obra permanece oculto, comparando-o a algo a ser descoberto no sentido visionário, assim como fazem os líderes, os místicos e os profetas, que, ao entrarem em contato com o aspecto soturno da vida, usam habilidades místicas para decifrarem os símbolos de sua época. Por essa razão, a leitura junguiana permitiu-nos investigar o sentido simbólico do romance O Túnel (1948), composto por trinta e nove capítulos relativamente curtos, em que se narra a confissão de um crime passional feita pelo próprio assassino, o pintor Juan Pablo Castel (protagonista), o qual tem uma personalidade introspecta, nutrindo uma paixão obsessiva por María Iribarne. 0 personagem alimenta uma breve ilusão de que María seria a única pessoa que poderia compreendê-lo como homem e como artista, idealizando-a, mas, ao longo da narrativa, descontrói essa imagem de mulher ideal e, por fim, acaba por assassiná-la.

De forma explícita, Sabato concebe o perfil psicológico do seu protagonista como um controverso conjunto de tensões existencialistas que nutrem seus estados de consciência e inconsciência, levando-o à insanidade. Revela-se, assim, o arquétipo da sombra ${ }^{4}$ como o fio condutor da trama, projetada nos conflitos psíquicos do personagem que o levam a degradar tanto o outro quanto a si mesmo, dominado pela sombra arquetípica ressignificada no universo pictórico do autor.

Ao reportarmos a situação específica vivenciada pelo personagem do romance, temos como parâmetro as circunstâncias de um universo ficcional que o impulsionaram até o crime, sem estereotipar toda timidez ou turbulência amorosa de forma patológica em situações externas à obra, uma vez que, desastrosamente, o protagonista do romance não consegue lidar com os sentimentos obsessivos pela mulher amada, afundando fatalmente nas profundezas de uma existência pessimista.

\section{A sombra arquetípica: o fio condutor da narrativa sabatiana}

Em O Túnel, Sabato traz à tona o arquétipo da sombra nos conflitos exacerbados da relação amorosa dos personagens, evidenciando sua imaturidade em "conduzir" o romance proibido, pois Iribarne é casada com Allende. Diante desse cenário, a narrativa sabatiana mostra as decisões legitimadas a partir do próprio desejo e impulsos de Castel, na ruptura das regras sociais que o mantinham

\footnotetext{
4 De acordo com os estudos junguianos, as sombras são os instintos oprimidos do eu "não aprovado" que rejeita sua mente consciente. Constituem a parte enterrada nas camadas mais profundas do ser. A sombra é o arquétipo que revela o lado obscuro da alma humana (JUNG, 2015).
} 
"civilizado" no sistema. O assassinato de Iribarne pode ser interpretado como o "renascimento" do pintor, o qual deixa para trás a persona social que funciona como uma espécie de escudo psíquico, ou a imagem que cada um escolhe para viver socialmente, comprometendo, porém, seu processo de individuação ${ }^{5}$. 0 trecho a seguir revela esse estado de espírito:

Um súbito furor fortaleceu minha alma e cravei muitas vezes a faca em seu peito e em seu ventre. Depois saí novamente para o terraço e desci com grande ímpeto, como se o demônio já estivesse para sempre em meu espírito. Os relâmpagos me mostraram, pela última vez, uma paisagem que nos fora comum. [...] Através da janelinha de minha cela, vi nascer um novo dia, com um céu sem nuvens (SABATO, 2000a, p. 148 -149).

Nesse trecho, é perceptível o comportamento obscuro do pintor, que atribui o crime cometido às forças demoníacas. Nesse caso, a imagem do demônio corresponde aos sentimentos de raiva da sombra arquetípica descrita na cena do crime. Diante do exposto, podemos perceber que Castel "vive" o mito de Hades na instabilidade emocional de sua vida amorosa, uma vez que se transforma obscuramente. Segundo Bolen (2002), o simbolismo arquetípico do Hades reflete-se de forma conturbada nas relações pessoais, sinalizando desequilíbrio emocional. Sabato desconstrói o mundo do personagem a partir da idealização de Iribarne, na frustração de viver um amor em sua totalidade.

Bomfim (2005) entende que o indivíduo sob efeito de possessão demoníaca entra em contato com o arquétipo do louco, na transição de uma linha tênue entre justiça e devaneio do núcleo arquetípico da sombra, que se origina dos próprios conflitos, tanto psíquicos quanto sociais, tal como em Dostoiévski, na luta do cosmos contra o caos da alma humana, no "subsolo" psicológico dos personagens.

\section{É nesse ponto que O Túnel apresenta a problemática da sombra arquetípica} na incomunicabilidade do artista que se fecha na obscuridade do existir, ao abster-se do convívio social, o que se torna uma espécie de preparo da condição de clausura. Castel aprisiona-se psiquicamente nos desejos, impulsos e devaneios, fazendo-se

\footnotetext{
${ }^{5} \mathrm{Na}$ concepção de C. G. Jung, o termo "individuação" remete a um processo através do qual o ser humano se torna realmente um "individuum psicológico", ou seja, ele se transforma em uma unidade autônoma e indivisível, se tornando uma totalidade. A individuação, no entanto, significa precisamente a realização melhor e mais completa das qualidades coletivas do ser humano; é a consideração adequada e não esquecimento das peculiaridades individuais, o fator determinante de um melhor rendimento social (JUNG, 2008a).
} 
carrasco de si na degradação da alma, que busca, por meio da violência, libertar-se da angústia decorrente de não ter a totalidade de um amor por ele idealizado.

Sabato (2000b) entende que a literatura deve se ocupar da busca de sentido da existência humana, como em obras cuja nudez e crueza expressam a verdade, sem mascarar a realidade dos fatos, na criticidade e na transformação da ideia, em concordância com o pensamento de Silveira (1992), ao afirmar que o homem, ao afastar-se de suas raízes, não manterá contato com o consciente, caso a sociedade também as renegue. De súbito, ocorrerão reações violentas dos sujeitos. Nessa perspectiva, Sabato leva-nos à complexidade de um romance policial, cujo personagem se refugia no vazio existencial da solidão, perdendo a sanidade na perigosa fragilidade de sua existência. Sartre (2014) alerta que os caminhos traçados se tornam demasiado difíceis nas adversidades, porém, paradoxalmente, eles são necessários à evolução humana, todavia, quando há um desequilíbrio da psique, isso pode resultar no aprisionamento do indivíduo no universo que ele próprio construiu (JUNG, 1991).

O Túnel suscita a questão do ser angustiado com a superficialidade do universo, carregando consigo seus próprios fantasmas e encarando a realidade de forma distorcida. A introspecção de Juan Pablo Castel exala ironia sobre a condição humana. Desse modo, a obra de Sabato dialoga com Memórias do Subsolo, de Dostoiévski (2009), originalmente publicado em 1864, sendo descrito por Kristeva (1989) como uma obra que insiste em apontar a existência humana como um sofrimento precoce ou primordial, à beira da consciência, embora portadora dos desejos e de um masoquismo primário que antecipa o sofrimento por meio da agressividade, haja vista que o homem não existe sem o convívio social, ainda que seja avesso a essa influência. Sobre essa condição, Lima (2019, p. 160) explica que

[...] o homem do subsolo, com orgulho e dignidade, opta heroicamente por ser um ser derrotado, um pária jogado nos subterrâneos da vida, a fim de não se juntar aos que ele considera os medíocres, isto é, os homens de ação.

Por isso, tais características equivalem aos domínios do Hades arquetípico, em que a alma humana, isolada, trava luta com as forças do Cosmos e do Caos, sendo a assinatura dos personagens dostoievskianos, chamados de caráter do subsolo (MELETÍNSKI, 2002). 
Shakespeare, Dostoiévski e Ernesto Sabato imprimem em suas obras as imperfeições humanas, competência que Campbell (1997) credita a escritores que estiveram abertos à verdade dos fatos, despindo seus personagens no confronto de opostos. Por outro lado, aqueles que não confrontam, de maneira equilibrada, a dualidade simbólica dos mitos hão de se perder na amargura de uma existência medíocre. Nesse contexto, o autor traz uma reflexão sobre o fato de que nem todos sabem lidar com a solidão, causando males a si e aos outros em razão do medo de não ser aceito, buscando no outro uma validação de sua própria existência.

Sabato (1973) aponta que as questões humanas em O Túnel se tornaram problemas psicológicos: a solidão tornara-se isolamento, o desespero converteu-se em ciúmes, e a paixão, em crime. Castel, em sua obsessão amorosa por María Iribarne aproveita-se da mulher através do sexo, vivendo momentos de prazer convertidos em situações constrangedoras por garantias de amor. Ele procura racionalizar seus excessos, buscando explicar seus delírios e justificar sua ação criminal, em inúmeros interrogatórios, acusações, ofensas, no efeito paranoide da síndrome de Otelo $^{6}$, uma referência aos ciúmes exacerbados do personagem de Shakespeare que assassina Desdêmona na ilusão sobre a infidelidade da mulher amada. A síndrome afeta homens e, menos frequentemente, mulheres.

A síndrome de Otelo pode aparecer por si só ou no decurso paranoide da esquizofrenia, do alcoolismo ou de outra dependência química, manifestando-se em recorrentes acusações de infidelidade, busca por evidências, repetidos interrogatórios ao outro, testes de fidelidade e perseguição. Por essa razão, a Psicologia Clínica refere-se a sujeitos que sofrem de ciúmes patológicos como portadores dessa síndrome, cuja significativa baixa autoestima, insegurança e sentimentos de posse em relação à pessoa amada revelam comportamentos extremamente exagerados ou inadequados, como perseguição e busca exaustiva de provas de traição, assim como ocorre na peça Otelo (1604), de Shakespeare, e também perceptível no trecho de $O$ Túnel:

[...] em determinados momentos ela parecia uma adolescente pudica e de repente ocorria-me a suspeita de que era uma mulher qualquer, e então um longo cortejo de dúvidas desfilava em minha mente: onde? como? quem?

\footnotetext{
${ }^{6}$ Denominação dada pelo psiquiatra inglês John Todd (1914-1987) em um artigo publicado em parceria com K. Dewhurst, intitulado "A Síndrome de Otelo: um estudo na psicopatologia do ciúme sexual" (TODD, 1955).
} 
quando? [...] Se algum dia eu desconfiar que você me enganou- dizia-Ihe com raiva -, mato você como a um cachorro (SABATO, 2000a, p. 69-71).

Nesse trecho, nota-se a intensidade irracional que ultrapassa a barreira da normalidade na distorção dos fatos, como em um estado alucinógeno, revelada nos desejos de atentar contra a vida de outrem, o que se torna fonte de sofrimento e tormento da imaginação obsessiva entregue a fantasias paranoides recheadas de perdas e humilhações. Desse modo, a Psicologia Analítica entende que a consciência se recusa a aceitar a verdade inegável, ficando presa à ilusão, e, por essa razão, a natureza da psique mergulha na obscuridade da sombra, na qual a alma transita entre os mistérios da humanidade. Caso o espírito seja desprovido de imaginação, o indivíduo nega-se a enxergar as próprias insuficiências.

Nesse âmbito, a narrativa de $O$ Túnel possibilita uma leitura simbólica da traição, que desencadeia diversas atitudes controversas no protagonista, estimuladas pelo ciúme, nutrindo o arquétipo da sombra, perceptível nas passagens que descrevem o perfil emocional do personagem. Paralelamente, Sabato transpõe para suas pinturas o caos mental de Castel (ao sentir-se traído, perdido, confuso), simbolizado nos tons avermelhados, em alusão aos atos violentos, bem como nos tons azulados, que dialogam com a conhecida fase azul de Picasso, o qual retratava o indivíduo solitário, desesperançado e absorvido pela própria sombra (condição em que se encontra o personagem sabatiano).

Para Sabato (2000b), a função do romance é trazer um temor existencial a um mundo em decomposição, entre restos de ideologias falidas, no qual a literatura é fundamental para expressar o caos humano e, assim, libertar o homem das obsessões recônditas e inexplicáveis do mundo. $O$ texto sabatiano incita as contradições humanas, observadas pela lente pessimista do autor, que desnuda a conveniência moral burlada por atos insanos, individuais ou coletivos, refletidos no total desdém de Castel pelos que o cercam, como é demonstrado no seguinte trecho do romance:

Voltei para a casa com a sensação de uma absoluta solidão. Em geral, essa sensação de estar só no mundo aparece mesclada a um orgulhoso sentimento de superioridade: desprezo os homens, acho que são sujos, feios, incapazes, ávidos, grosseiros, mesquinhos; minha solidão não me assusta, é quase olímpica. Mas naquele momento, como em outros semelhantes, encontrava-me só em consequência de meus piores atributos, de minhas baixas ações. Nesses casos sinto que o mundo é desprezível, mas compreendo que eu também faço parte dele (SABATO, 2000a, p. 86). 
A condição existencialista de Sabato é extraída dos contextos vividos intensamente por Castel como instrumento de apreensão negativa da realidade, revelada na crueza das palavras do personagem, que se julga acima dos meros mortais, que não correspondem ao seu intelecto e talento. A solidão existencial atrai Castel e María, mas não lhes garante a comunhão de sentimentos, pois os ciúmes se exacerbam nas inúmeras interrogações de Castel, as quais não se apaziguam com as respostas de María. Sendo assim, a literatura materializa a dialética existencial na trama narrativa, identificando os leitores com determinado personagem, de modo que o romance propicia ao leitor refletir sobre os próprios "túneis" criados ao longo da vida.

Conforme Coddou (1966), a intenção do autor é penetrar até o último reduto do caráter narcísico do personagem, investigando a condição humana em suas limitações e absurdos, para assim compreender seus pensamentos, sentimentos e ações, como evidenciado no seguinte trecho.

Como eu ia dizendo, meu nome é Juan Pablo Castel. Vocês poderão perguntar-se o que me leva a escrever a história do meu crime (não sei se já disse que vou relatar meu crime) e, sobretudo, a procurar um editor. Conheço bem a alma humana para prever que pensarão em vaidade. Pensem o que quiserem: não ligo a mínima; faz tempo que não ligo a mínima para a opinião e a justiça dos homens. Suponham, então, que estou publicando esta história por vaidade. Afinal, sou feito de carne, ossos, cabelo e unhas como qualquer outro homem e acharia muito injusto que exigissem de mim, logo de mim, qualidades especiais; às vezes nos julgamos super-homens, até percebermos que também somos mesquinhos, sujos e pérfidos (SABATO, 2000a, p. 9).

O escritor apresenta os estados de solidão e de loucura sob a ótica do próprio assassino, alimentando a esperança de que alguém compreenda os motivos que o impulsionaram ao final trágico, sendo que o problema metafísico se integra à persona do protagonista, como se observa no final do enunciado: "às vezes nos julgamos super-homens, até percebermos que também somos mesquinhos, sujos e pérfidos" (idem). $O$ efeito de admitir o erro mescla-se a uma certa manipulação na qual julga a imperfeição humana, passível de cometer faltas tão graves quanto as de um assassinato, o que se repete em outras partes da narrativa: "embora não tenha ilusões acerca da humanidade em geral, nem dos leitores destas páginas em particular, anima-me a tênue esperança de que alguma pessoa chegue a me entender. MESMO QUE SEJA UMA ÚNICA PESSOA" (SABATO, 2000a, p. 11). Dessa forma, o pintor, que se transformou em um criminoso, busca eternizar na literatura o desfecho trágico do caso amoroso, em uma busca incoerente de aprovação pelo crime praticado. 
De acordo com Ferreira e Aquotti (2009, p. 2), "o ciúme é um sentimento que surge a partir da insegurança, medo de perda, dependência, síndrome da inferioridade". Esse sentimento é a válvula que impulsiona o simbolismo da sombra no romance, manifestada no sentimento de posse, na desconfiança, na sensação de perda do objeto de desejo (a mulher amada) e na traição. Na dialética da solidão que aproxima Castel e Maria, o relacionamento não preenche a crise existencial do pintor; ao contrário, aumenta seu estado de solidão. Em Castel, os excessos oscilam entre a superioridade narcísica e a inferioridade surgida da insegurança quanto ao amor de María, bem como da frustrada tentativa de comunicar-se com o exterior, que resulta no descontrole emocional ao perceber que a mulher amada não faz mais parte de seu túnel.

Sabato (2003) entende que a literatura permite expressar uma profunda descrição dos sentimentos, das paixões e das ideias do mundo inconsciente e subconsciente de seus personagens, o que não implica no abandono do mundo externo, consistindo na verdadeira dimensão e alcance do ser humano. Pode-se então compreender que a condição humana traz a recompensa oferecida aos homens capazes de abandonar seus medos e ir em busca de conhecimentos, com a coragem de descrever a realidade sem véus embelezadores que limitam sua esfera de poder (ELIAS, 1991). Diante dessa perspectiva,

\footnotetext{
Um romance profundo não pode deixar de ser metafísico, pois sob os problemas familiares, econômicos, sociais e políticos em que os homens se debatem estão sempre os problemas últimos da existência: a angústia, o desejo de poder, a perplexidade e o temor diante da morte, o anseio de absoluto e de eternidade, a revolta diante do absurdo da existência (SABATO, 2003, p. 191).
}

Na escrita de Sabato, temos a condição embrionária do mundo melancólico de um sujeito do tipo introvertido (de ordem espiritual, mas de uma postura afastada de comunicação) - personagem que se afasta do mundo, perdendo-se no pessimismo diante da própria existência. Portanto, a incomunicabilidade de Castel mostra ao público a solidão dos personagens entregues ao fardo do existir, vivenciando situações adversas que tendem ao pessimismo de estar em um mundo assolado pela sombra.

\section{Imagens arquetípicas presentes na pintura e no romance 0 Túnel, de Ernesto Sabato}


De acordo com os estudos junguianos, as sombras são os instintos oprimidos do eu "não aprovado" que rejeita sua mente consciente. Parte enterrada nas camadas mais profundas do ser, a sombra é o arquétipo que revela o lado obscuro da alma humana. Na narrativa sabatiana, estabelecemos a construção da sombra arquetípica perceptível no drama interno do protagonista, Castel, acentuado nos sentimentos de ciúme, desespero, dor, loucura, traição, tristeza, ódio e constante solidão, os quais são representados visualmente nas pinturas do escritor em seres que expressam esses estados de espírito sombrio, com o uso de tonalidades escuras. Segue o trecho da obra em que se evidencia a dualidade dos sentimentos:

As horas que passamos no ateliê foram horas que nunca esquecerei. Meus sentimentos, durante todo aquele período, oscilaram entre o amor mais puro e o ódio mais desenfreado, ante as contradições e as inexplicáveis atitudes de María; de repente acometia a suspeita de que fosse fingimento. (SABATO, 2000a, p. 68-69).

Nesse trecho, é perceptível a construção da sombra arquetípica presente nos conflitos psíquicos de Castel, que age passionalmente, perdendo o senso de julgamento e, portanto, mostrando-se incapaz de discernir seus atos. Sabato transpõe a confusão mental para a narrativa pictórica, conforme o seguinte trecho do romance: "Minha cabeça é um labirinto escuro. Às vezes há como relâmpagos que iluminam alguns corredores. Nunca sei bem por que faço certas coisas" (SABATO, 2000a, p. 37). Outra ironia está no fato de o personagem ter conhecido María em uma de suas exposições, quando, fixamente, ela olhava para a janela da obra "Maternidade", como se entendesse o propósito daquela composição, surpreendendo o artista, pois nenhum dos outros convidados havia percebido a importância daquele símbolo. Castel decide aproximar-se da mulher que contemplava sua obra, mas a perde entre as pessoas, então passa semanas imaginando um possível reencontro. Quando isso acontece, ele, precipitadamente, exige dela a interpretação da janela. Atônita, María esquiva-se da resposta, porém cede à curiosidade do pintor. Para Castel, o simbolismo da janela remete a um estado de solidão e angústia de um túnel metafórico que muitos não entendem e não conseguem transpor. María também interpreta a composição de forma semelhante, o que enseja o envolvimento emocional entre eles:

[...] melhor seria dizer que a senhora sente como eu. A senhora olhava aquela cena como eu mesmo poderia ter olhado em seu lugar. Não sei o que pensa e tampouco sei o que penso, mas sei que pensa como eu (SABATO, 2000a, p. 39). 
Diante desse contexto, analisamos as seguintes pinturas de Sabato:

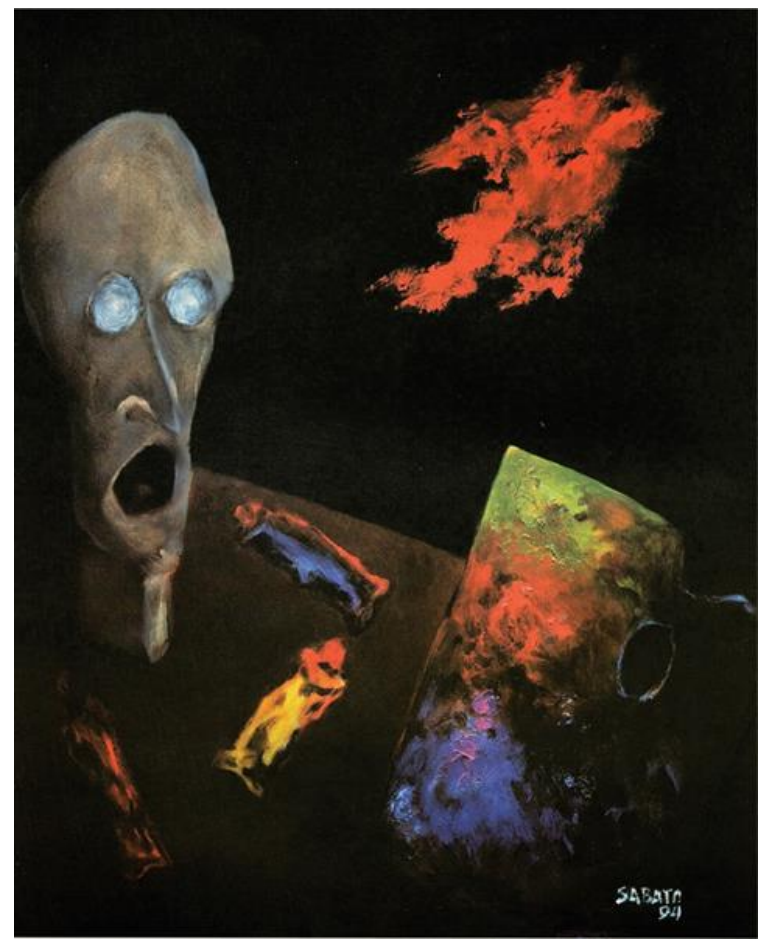

Fig. 1. Algo ocorrido em meu Ateliê (1994), Ernesto Sabato. Óleo sobre tela $40 \times 50 \mathrm{~cm}$. Fonte: Sabato (1994)

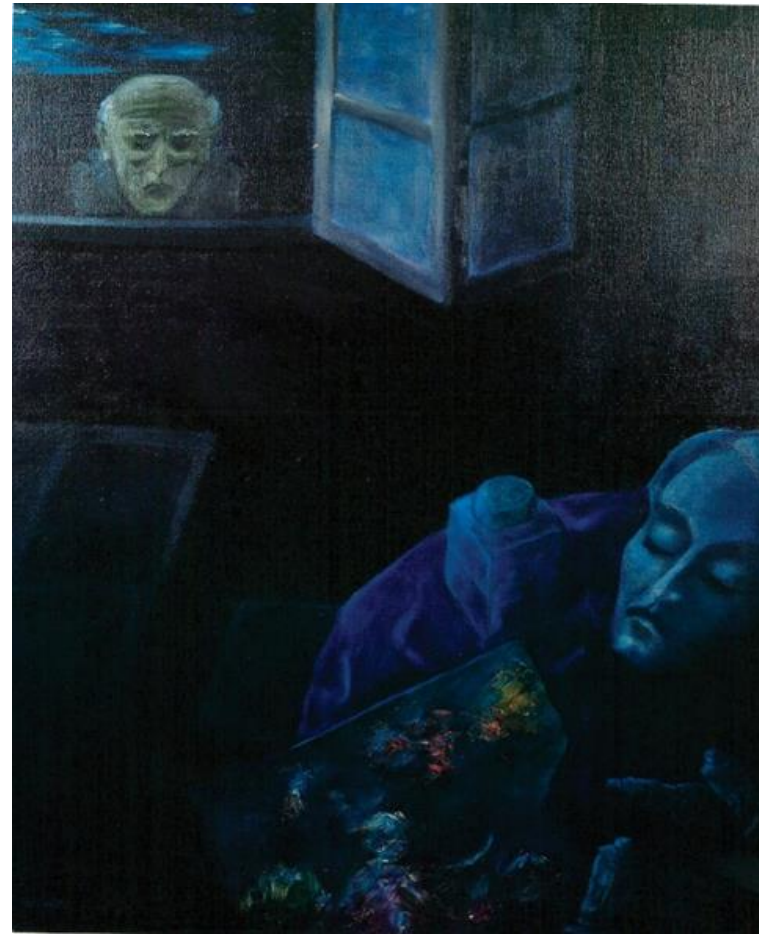

Fig. 2. Alguém observa o ateliê de um pintor ausente (1981), Ernesto Sabato. Oleo sobre tela $50 \times 60 \mathrm{~cm}$. Fonte: Sabato (1991)

$\mathrm{Na}$ pintura intitulada Algo ocorrido em meu Ateliê (1994), à direita da composição, apresenta-se uma cabeça que expressa pânico e desespero. Ambas as pinturas tem como cenário um ateliê, como também se lê no seguinte trecho do romance: "As horas que passamos no ateliê foram horas que nunca esquecerei. Meus sentimentos, durante todo aquele período, oscilaram entre o amor mais puro e o ódio mais desenfreado" (idem). É o ateliê, portanto, local dos encontros íntimos e também das violentas discussões com María.

Observa-se que os pontos de luz (detalhes em amarelo, azul e vermelho nos tubos de tintas a óleo repetem-se no godet ${ }^{7}$ do artista, onde há também a presença da cor verde sobreposta em um leve tom de amarelo) são pinceladas crispadas, que

\footnotetext{
7 “Também conhecida por paleta, trata-se de uma chapa de madeira, louça ou plástico sobre a qual os pintores dispõem e misturam as tintas enquanto pintam. Tem um orifício para o polegar e também um recuo ou reentrância ao lado do orifício para segurar a paleta com os dedos indicador e médio, e assim permite que as duas mãos do pintor fiquem livres. Portanto, um acessório de pintura" (BITENCOURT, 2011, p. 28).
} 
sinalizam movimentos bruscos das tintas jogadas no cenário, representando um frenesi mental do artista. A notável mancha avermelhada do lado esquerdo está inclinada, em uma referência ao voo de um pássaro (animal recorrente nas pinturas de Sabato, sinalizando mau presságio, inserido nas composições de forma ameaçadora), que voa em céus com tonalidades excessivamente escuras e avermelhadas, indicando o perigo iminente em torno dos personagens, retratados como em um pesadelo.

Ainda no primeiro plano, destaca-se o godet com intensa mistura de cores, podendo ser interpretado como a marca da dedicação solitária do artista em horas ininterruptas no ateliê. A cabeça humana torna-se o elemento central da composição, e parte disso deve-se à enigmática expressão e à cavidade dos olhos intensamente acesos como faróis luminosos, que também remetem à cegueira metafórica de não se enxergar a realidade. A cabeça ainda apresenta uma tonalidade em que variados tons de cinza se mesclam aos marrons, como em uma escultura feita em argila (material que pode ser moldado e enrijecido no forno), o que podemos comparar, simbolicamente, ao processo de construção da mente humana, que, gradativamente, molda-se mediante as influências do coletivo.

Sabato (2003) entende que a humanidade se agarra a esperanças que se dissipam em contínuas decepções, perdendo o sentido da vida, os valores e crenças, as forças físicas e divinas. Castel personifica a descrença no humano, carregando em si um cemitério de interrogações. Tem na pintura a profissão, sendo sua arte também reflexo das inquietações pessoais, como se vê no primeiro capítulo, em que ilustra sua indignação com a humanidade, reportando-se aos horrores da guerra:

\footnotetext{
Quantas vezes passei horas prostrado num canto escuro do ateliê, depois de ler uma notícia nas páginas policiais! [...] Que o mundo é horrível é uma verdade que não requer demonstração. Em todo caso, bastaria um fato para prová-lo: num campo de concentração, um ex-pianista queixou-se fome e foi obrigado a comer uma ratazana, só que viva (SABATO, 2000a, p. 7-8, grifo do autor).
}

Castel mostra quão frágil se torna a humanidade diante da sombra coletiva que se apresenta nas relações de poder, na condição de miserabilidade e de subjugação dos seres oprimidos. Há uma ironia no fato de o pintor horrorizar-se com o que lia nas páginas policiais, ao tempo em que se mostra incapaz de perceber que, ao subjugar María, adota semelhante atitude de poder sobre a vida de outra pessoa. Assim, o diálogo existencialista sartreano apresenta-se narcisicamente no ciúme 
patológico de Castel. Para Carrasco (2019), estamos sempre sós, pois, mesmo na companhia de outras pessoas, estamos em nossa companhia. Cada pessoa experimenta a sensação de solidão, sendo que alguns se sentem bem com isso, enquanto outros se sentem apavorados e até desesperados.

A pintura de Sabato exala medo, angústia e solidão, como em seu texto literário, no qual Castel descreve em vários momentos seu estado, como no trecho "Minha cabeça é um labirinto escuro. Às vezes há como relâmpagos que iluminam alguns corredores". O autor plasma no texto visual a sombra arquetípica envolta nos delírios do personagem, assim, ao retirar a persona (máscara social) que o protege, o personagem evidencia o contraste dos labirintos e dos relâmpagos da mente, na angústia de não poder assumir publicamente a mulher que transpôs a barreira de sua solidão. Desse modo, o simbolismo da cabeça faz alusão a um crânio decapitado, que traz a visão macrocósmica do homem na percepção de si na totalidade.

A segunda tela, intitulada Alguém observa o ateliê de um pintor ausente (1981), tem como destaque uma cabeça masculina que, na janela, observa uma cabeça feminina "descansando" sobre uma mesa junto aos materiais de pintura, como se estivesse morta. Interpreta-se essa imagem como uma alusão à violência sofrida por María, em referência ao romance. Apesar de o assassinato ter sido em outro local, o cenário conturbado do ateliê traz indícios do crime. Além disso, a narrativa pictórica dialoga com os elementos oníricos do Surrealismo e o transbordar de emoções do Expressionismo, na percepção fantasmagórica de seus personagens, levando Sabato a ressignificar o intertexto das pinturas surrealistas que simbolizavam as obscuridades psicológicas do mundo moderno.

O simbolismo da janela presente na narrativa literária surge no quadro Maternidade, no qual Juan Pablo pinta uma mãe segurando seu filho no colo como cena principal, enquanto, secundariamente, uma outra mulher caminha solitária na beira do mar, sendo vista por meio de uma janela. Tal cena é interpretada como o túnel existencial do personagem, que necessita ultrapassá-lo para se comunicar com alguém que o compreenda. Entende-se, assim, que a solidão não significa a ausência de pessoas à nossa volta, mas sim o fato de não podermos comunicar-lhes as coisas que julgamos importantes, ou mostrar-Ihes o valor de pensamentos que lhes parecem improváveis (JUNG, 1992).

Sabato apresenta tal dualidade à proporção que Castel encontra na solidão o refúgio da superficialidade humana, ao tempo que busca em María a companhia para 
curar seus conflitos. Por outro lado, o romance traz a interrogação sobre a totalidade humana à medida que temos consciência da morte como a única certeza humana, que é também a mais angustiante. Em outras palavras, a angústia não é somente sofrimento, mas também sensação de impotência do indivíduo frente a uma situação. No drama sabatiano, a vida de María foi ceifada por uma decisão insana e egóica do amante, alegando ele que ela o havia "abandonado", entregando-o à solidão, como se evidencia no trecho: "Pondo minha mão esquerda sobre seus cabelos, respondi: - Tenho que matar você, María. Você me deixou sozinho" (SABATO, 2000a, p. 147). Possesso de ciúmes, Castel lança a mulher na obscuridade eterna de um túnel de que não se retorna.

Sabato (2003) reflete sobre a condição metafísica em sua produção literária, considerando-a uma estética melancólica, em que a problemática do homem parece rescindir-se no pacto primeiro entre o mundo e o ser humano, o qual encontra-se como estrangeiro solitário e desamparado, psicologicamente e espiritualmente. Assim, "O homem sente-se então na intempérie, o antigo lar, destruído. E se pergunta sobre seu destino" (SABATO, 2003, p. 65). Diante dessa reflexão sobre a condição metafísica no romance, o escritor abre a discussão sartreana de destino, na qual o homem escolhe e reconhece as consequências, na liberdade de escolha que proporciona a conversão no autoconhecimento ou na degeneração do sujeito. Sabato, dessa forma, desmascara a persona social através do ciúme, da indiferença, do rancor e da vingança.

O simbolismo da janela transposto do texto literário para a pintura "Alguém observa o ateliê de um pintor ausente" (1981), é acentuado na cor azul, a qual demonstra que a tristeza inunda a composição do artista, como é perceptível no contemplar triste do homem, em diálogo com a clausura de Castel, que passa a pintar seus quadros na prisão, ausentando-se e, dessa forma, abandonando o ateliê. "Pelo menos posso pintar, embora suspeite de que os médicos riem às minhas costas, assim como suspeito de que riram durante o processo quando mencionei a cena da janela" (SABATO, 2000a p. 150). Com a perda da sanidade, o ato de pintar na prisão continua sendo uma forma de comunicação do personagem perdido nos próprios devaneios, simbolizando a dor. Na pintura, a presença do homem na janela pode ser atribuída ao próprio Juan Pablo, que envelhece e sonha com o ateliê abandonado, enquanto a imagem de María, plasmada na cabeça da mulher (semelhante a uma escultura), permanece triste e de olhos fechados, em uma alusão ao crime. 
Iribarne se vê atraída pelo artista, mas se depara com o homem imaturo, pessimista e violento, diferente da persona pública. Essa personagem pode ser entendida como a imagem arquetípica da mulher adúltera que paga com sua própria vida o preço de sua traição, ou o preço do seu pecado. Sabato reflete sobre a importância da condição humana nas artes plásticas através do Surrealismo:

[...] o surrealismo teve o alto valor de permitir-nos indagar para além dos limites de uma racionalidade hipócrita e, em meio a tanta falsidade, oferecernos um novo estilo de vida. Muitos homens, desse modo, pudemos descobrir nosso ser autêntico (SABATO, 2000b, p. 63).

Nesse sentido, de forma sutil, a morte aparece nas telas do escritor, no simbolismo de cabeças lançadas no ateliê, no cenário lúgubre, nas tonalidades escuras, nas expressões ora tristes, ora aterrorizadas dos seres fantasmagóricos imersos nos conflitos dos túneis existenciais. Sabato (1991) acredita que o artista sublima o lado demoníaco na obra de arte, a exemplo de Van Gogh e de Dostoiévski, torturados por seus demônios existenciais. Por essa razão, faz-se necessário compreender os simbolismos da janela e do túnel, que convergem para sentidos semelhantes, como portais que exercem condição de passagem de um estado a outro no acesso à consciência, uma vez que a luz atinge as trevas, ou faz o percurso contrário. Com o privilégio de investigarmos a relação intersemiótica em $O$ Túnel, analisamos os conflitos dos personagens plasmados no texto visual do escritor/pintor.

\section{Considerações finais}

No romance O Túnel (1948), do escritor argentino Ernesto Sabato, percebemos a construção da imagem arquetípica da sombra por meio do protagonista, o pintor Juan Pablo Castel, que vive um conturbado relacionamento amoroso com María Iribarne, cuja imagem é desconstruída ao longo da narrativa. A partir disso, tal como em Otelo, de Shakespeare (1604), começam as dúvidas, a angústia e os ciúmes, aos quais se acrescentam sentimentos de frustação, levando o personagem a atitudes insanas, ou seja, gradativamente, a sombra apodera-se do artista, que chega ao ponto de assassinar María Iribarne. Desse modo, a partir do contexto de um romance policial, investigamos a extensão da narrativa para as pinturas do escritor, que expressam a obscuridade e a tensão presentes no texto literário. 
As pinturas Algo ocorrido em meu Ateliê (1994) e Alguém observa o ateliê de um pintor ausente (1981) apresentam o simbolismo da morte no ateliê do pintor, carregado de tons escuros, na metáfora do inconsciente atormentado de Castel e cenário dos encontros furtivos com María, que traduzem a atmosfera lúgubre do romance. Constitui-se, assim, um processo de entrelaçamento entre o texto literário e o visual, perceptível na solidão e nas faces dos personagens nas pinturas, presos na própria angústia existencial, evidenciando a qualidade simbólica da sombra na conduta dos personagens que atravessam túneis tortuosos.

Lisboa (2016) aponta que a consciência da morte é vista pela filosofia existencial como um dos principais elementos de individualização do homem, ou seja, morrer é inevitavelmente um ato solitário, colocando em evidência as escolhas feitas anteriormente como irreversíveis, de modo que nada resta além de encarar a história vivida, a qual não pode mais ser reescrita. Nesse sentido, Sabato (2000b) acredita que um romance profundo surge em situações-limite da existência, nas dolorosas encruzilhadas em que intuímos a inescapável presença da morte, e a ressignifica em seu texto pictórico.

Nessa perspectiva, podemos compreender que o arquétipo da sombra apresentado no romance foi transposto intersemioticamente para as pinturas de forma perspicaz, sendo que o autor, valendo-se dos estilos expressionista e surrealista, apresenta no texto visual a sombra psíquica do personagem. Dessa forma, as imagens arquetípicas, como estruturas universalmente reconhecidas, permitem ao homem reconhecer-se nas mais diversas situações arquetípicas e as identificar na produção de sentido e integração moral. Mediante a personalidade e atitudes de um homem do subterrâneo, buscamos compreender a sombra que se faz presente desde o início da narrativa, quando é feita a confissão do crime, sendo Castel o narrador da trama.

Nesta pesquisa, tomamos o conceito de sombra como o fio condutor da narrativa sabatiana, ressignificado nas imagens arquetípicas construídas a partir do desequilíbrio emocional revelado na agressividade física e psicológica do protagonista, cujo lado obscuro possibilitou a correlação com a síndrome de Otelo. Por essa razão, o estímulo da sombra arquetípica está ligado ao simbolismo da solidão, da morte e das influências negativas da condição humana.

Consideramos que as discussões acerca do romance O Túnel (1948) oportunizaram uma reflexão crítico-interpretativa sobre a relação intersemiótica entre 
as imagens arquetípicas do texto literário e as pinturas do escritor Ernesto Sabato, que as ressignifica e as imortaliza na arte da escrita e nas artes plásticas. Buscamos, pois, nesse breve percurso analítico, familiarizar o leitor com os diálogos possíveis entre as interartes, fazendo-o perceber como Sabato plasmou a sombra arquetípica de Castel em personagens solitários, com faces desesperadas, diante do sofrimento latente da atmosfera soturna de suas telas, oferecendo-nos a sensação de continuidade da narrativa literária.

\section{Referências}

BOLEN, Jean Shinoda. Os deuses e o homem: uma nova psicologia da vida e dos amores masculinos. Tradução: Maria Silvia Mourão Netto. São Paulo: Paulus, 2002.

BITENCOURT, Amauri Carboni. Técnicas de pintura. 2. ed. Indaial: Uniasselvi, 2011.

BOMFIM, Edilma Acioli. Razão Mutilada: ficção e loucura em Breno Accioly. Maceió: Edufal, 2005.

CAMPBELL, Joseph. O herói de mil faces. Tradução: Adail Ubirajara Sobral. 9. ed. São Paulo: Cultrix, 1997.

CARRASCO, Bruno Barbedo. Existencialismo e Psicologia. 2. ed. [S. I.]: ex-isto, 2019.

CODDOU, M. La estructura y la problemática existencial de El Túnel de Ernesto Sábato. Disponível em: http://www.letras.s5.com/sabato070902.htm. Acesso em: 07 dez. 2019.

DOSTOIÉVSKI, Fiódor. Memórias do subsolo. Tradução: Boris Schnaiderman. São Paulo: Editora 34, 2009.

ELIAS, Norbert. A condição humana. Considerações sobre a evolução da humanidade por ocasião do quadragésimo aniversário do fim de uma guerra. Tradução: Manuel Loureiro. Lisboa: DIFEL, 1991.

FERREIRA, Kátia; AQUOTTI, Marcus. Crime passional: quando o ciúme mancha a paixão de sangue, 2009. Disponível em:

http://www.adpesp.org.br/artigos_exibe.php?id=126. Acesso em: 20 set. 2019.

JUNG, Carl Gustav. Aion: estudos sobre o simbolismo do si-mesmo. Tradução: Dom Mateus Ramalho Rocha. 3. ed. Petrópolis: Vozes, 1990.

JUNG, Carl Gustav. Eu e o inconsciente. Tradução: Dora Mariana R. Ferreira da Silva. 21. ed. Petrópolis: Vozes, 2008a. 
JUNG, Carl Gustav. O homem e seus símbolos. Tradução: Maria Lúcia Pinho. 5. ed. Rio de Janeiro: Nova Fronteira, 2008b.

JUNG, Carl Gustav. O espírito na arte e na ciência. Tradução: Maria de Moraes Barros. Petrópolis: Vozes, 2013.

JUNG, Carl Gustav. Os arquétipos e o inconsciente coletivo. Tradução: Maria Luíza Appy e Dora Mariana R. Ferreira da Silva. Petrópolis: Vozes, 2002.

JUNG, Carl Gustav. Sobre sentimentos e a sombra: sessões de perguntas de Whinterthur. Tradução: Lorena Ritcher. 2. ed. Petrópolis: Vozes, 2015.

JUNG, Carl Gustav. Psicologia e alquimia. Petrópolis: Vozes, 1992.

JUNG, Carl Gustav. Tipos psicológicos. Tradução: Lúcia Mathilde Endlich Orth. Petrópolis: Vozes, 1991.

KRISTEVA, Júlia. Sol negro: depressão e melancolia. Tradução: Carlota Gomes. 2. ed. Rio de Janeiro: Editora Rocco, 1989.

LEITE, Dante Moreira. Psicologia e Literatura. São Paulo: Nacional, 2002.

LIMA, Wanderson. Ensaios sobre literatura e cinema. Vinhedo: Horizonte, 2019.

LISBOA, Camila Pereira. Introdução ao existencialismo: perspectivas literarias. Problemata: R. Intern. Fil., v. 7, n. 2, p. 254-67, 2016.

MELETÍNSKI, E. M. Os arquétipos literários. Tradução: Aurora Fornoni Bernardini e Homero Freitas de Andrade e Arlete Cavaliere. 2. ed. São Paulo: Ateliê Editorial, 2002.

MUSEU DE ARTE DE SÃO PAULO. Instituto Cultural Brasil-Argentina. Ernesto Sabato- Pinturas, 1994.

SHAKESPEARE, William. Otelo: o mouro de Veneza. Tradução de Bárbara Heliodora. Rio de Janeiro: Lacerda Ed,1999 (texto original de 1604).

SABATO, Ernesto. El pintor Ernesto Sabato. Madrid: Raycar, S. A., 1991.

SABATO, Ernesto. Hombres y Engrenajes. Madrid: Alianza Editorial, 1973.

SABATO, Ernesto. O Túnel. Tradução: Sérgio Molina. São Paulo: Companhia das Letras, 2000a.

SABATO, Ernesto. Antes do fim: memórias. Tradução: Sérgio Molina. São Paulo: Companhia das Letras, 2000b.

SABATO, Ernesto. O escritor e seus fantasmas. Tradução: Pedro Maia Soares. São Paulo: Companhia das Letras, 2003. 
SABATO, Ernesto. A Resistência. Tradução: Sérgio Molina. São Paulo: Companhia das Letras, 2008.

SARTRE, Jean-Paul. Esboço para uma teoria das emoções. Tradução: Paulo Neves. Porto Alegre: L\&PM, 2014.

SILVEIRA, Nise da. O mundo das imagens. São Paulo: Editora Ática, 1992.

TODD, J.; DEWHURST, K. The Othello syndrome: a study in the psychopathology of sexual jealousy. Journal of Nervous and Mental Disease, n. 122, p. 367-74, 1955. 